\title{
A Review of Flood Warning Systems in Developed and Developing Countries
}

\author{
Saysoth Keoduangsine, Robert Goodwin, and Paul Gardner-Stephen
}

\begin{abstract}
Flood warning systems have been developed and applied worldwide in both developed and developing countries using different approaches and technologies. Nevertheless people in the flood risk areas continue to be affected by floods; these affects include extensive property damage and loss of life. In developing countries, the flooding impacts have been more harmful than in developed countries for the same severity of flood. A number of factors contribute to these losses such as the data collection process, the flood warning channels and an inappropriate technology adoptation. This paper reviews the techniques of a number of flood warning systems, discusses factors contributing to the extensive damage to property and loss of life in developing countries, and finally the paper makes recommendations, draws conclusions and suggests future work.
\end{abstract}

Index Terms-Developing countries, flood methods, flood warning system.

\section{BACKGROUND}

Floods are natural hazards that occur due to heavy rain, cyclones and storms and lead to large losses of property and lives. Developing countries seem to be more vulnerable to damage from floods than developed countries. Examples of flooding in developing countries include the following cases.

The 2010 Pakistan floods began in late July 2010, as a result of heavy monsoon rain; the floods directly affected about 20 million people via destruction of property, livelihood and infrastructure. About 2,000 people died and the total economic impact was \$US40 billion [1].

During December 2012 the Philippines suffered heavy floods caused by typhoon Bopha, in this event1020 people were confirmed dead, 844 people were missing, 1.2 million families were affected and total damages estimated at U\$1 billion [2].

Annual floods in the Lower Mekong Basin (LMB) along the Mekong River and its tributaries result in a massive loss of life and property damage. For instance, in 2010 floods affected the LMB countries (Cambodia, Laos, Thailand and Vietnam). The floods destroyed more than 64 million hectares of rice paddy, affected 1.1 million households of about 5 million people, the total property damage was \$US1.2 billion and at least 98 people died [3].

Developed countries were affected by severe floods, but with less life loss. A number of floods hit Australia during the years 2011 and 2012, the floods swept across Queensland, New South Wales and Victoria. In 2011, the floods forced the evacuation of thousands of people from towns and cities, the damage was in excess of $\$ A 15$ billion, over 200,000 people

Manuscript received August 20, 2013; revised November 1, 2013.

The authors are with the Flinders University of South Australia (e-mail: \{keod0001, robert.goodwin, paul.gardner-stephen\} @flinders.edu.au). were affected and 35 people died [4].

In 2012 significant flooding, due to the Sandy storm, hit New York and New Jersey, in the USA. The preliminary damage estimates were near US\$50 billion, 650,000 houses were either damaged or destroyed, about 8.5 million people were affected and there were about 100 directly related deaths [5], [6].

The recent extreme flood, in central Europe during June 2013, due to heavy rain, swept through Germany, the Czech Republic, Austria, Slovakia and Hungary, thousands of people were evacuated from their homes in flood-prone areas. The total cost of damage was about $€ 12$ billion and 21 deaths were reported [7].

TABLE I: A SumMARY OF PROPERTy DAMAgE AND LOSS OF LIVE DUE TO FLOODS IN DEVELOPED AND DEVELOPING COUNTRIES

\begin{tabular}{|c|c|c|c|c|c|}
\hline $\begin{array}{l}\text { Country } \\
\text { category }\end{array}$ & Countries & Year & $\begin{array}{l}\text { Property } \\
\text { damage }\end{array}$ & $\begin{array}{l}\text { Affected } \\
\text { people }\end{array}$ & $\begin{array}{l}\text { Loss of } \\
\text { life } \\
\text { (people }\end{array}$ \\
\hline \multirow{3}{*}{$\begin{array}{l}\text { Developed } \\
\text { countries }\end{array}$} & Australia & 2011 & $\mathrm{~A} \$ 15 \mathrm{bn}$ & $\begin{array}{l}0.2 \\
\text { million }\end{array}$ & 35 \\
\hline & $\begin{array}{l}\text { United } \\
\text { States }\end{array}$ & 2012 & U\$50bn & $\begin{array}{l}8.5 \\
\text { million }\end{array}$ & 100 \\
\hline & $\begin{array}{l}\text { European } \\
\text { countries }\end{array}$ & 2013 & $€ 12$ bn & 5 million & 21 \\
\hline \multirow{3}{*}{$\begin{array}{l}\text { Developing } \\
\text { countries }\end{array}$} & Pakistan & 2010 & U\$40bn & 20 million & 2000 \\
\hline & $\begin{array}{l}\text { The } \\
\text { Philippines }\end{array}$ & 2012 & U\$1bn & $\begin{array}{l}1.2 \\
\text { million }\end{array}$ & 1020 \\
\hline & $\begin{array}{l}\text { The LMB } \\
\text { countries }\end{array}$ & 2010 & U\$1.2bn & 5 million & 98 \\
\hline
\end{tabular}

The Table I shows developing countries suffer greater impact then developed countries for both property damage and loss of life. The next section, a review flood warning systems in both categories of the countries is presented.

\section{FLOOD WARNING SYSTEMS (FWS) AROUND THE WORLD}

In this section, we discuss techniques of the flood warning systems which have been developed and implemented worldwide.

\section{A. FWS in Developing Countries}

The Mekong River passes through Laos which is affected by annual floods during the monsoon season. The flood warning systems in the country are operated by the Department of Meteorology and Hydrology (DMH) and the Mekong River Commission (MRC) [8].

To collect data to support the systems, the data centres receive real-time data on 15-minute intervals from the monitoring stations along the Mekong River and its mainstream tributaries via the Global System for Mobile communication (GSM) networks, but there are delays in data transmission from some remote monitoring stations to the 
data centre due to weak cellular signals [9].

For flood forecasting, the data is processed and prepared bulletins are issued twice a day during the monsoon season. For real-time monitoring, the real-time graphs of water level and rainfall are created and published online [10].

In the case of floods the flood information is mainly disseminated by public media through radio, television stations and newspapers. The DMH as well shares the flood information with the Disaster Management Committee (DMC), including national, provincial and district committees. The chairperson of each committee acts as a first contact point for the warnings as illustrated in Fig. 1.
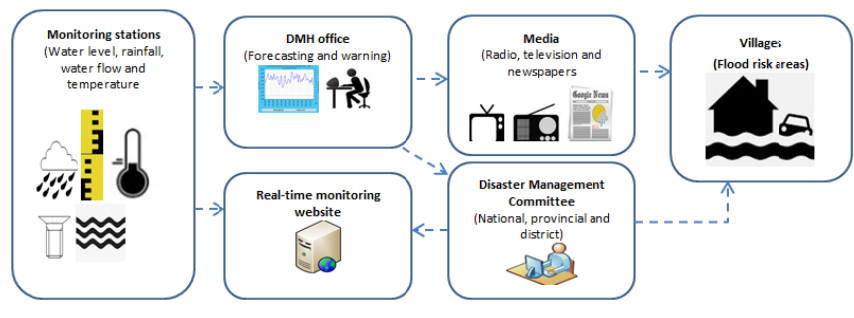

Fig. 1. Flood warning systems in Laos(adapted from[11]).

To respond to a warning the chief of a village gets flood information from the district DMC and uses the public address system. Household heads are called to the meeting in the village chief's house or a temple to discuss activities in preparation for an incoming flood. In addition, the DMC and online users can get weather information from the real-time monitoring website [8].

In China, flood forecasting and warning and systems have been implemented by setting up hydrological stations nationwide, including rainfall and water level stations. The data is transmitted via mobile phone networks, two-way radios, and satellite to the central government every hour. Hydrological models and geographic information system (GIS) software are used for flood forecasting. Flood warnings are issued through the broadcast media to the public, and via telephone and SMS messages to flood control offices, including country, town and village levels. The system allows users to make inquiries of the database, and present data in web-based GIS format and visual alert information, but the system does not have real-time warnings to people in a flood risk area[12], [13].

Because of its geographic location, the Philippines is exposed to a variety of hazards such as typhoons and floods. Before disseminating a flood warning to the public, hydrological data (rainfall, water level and water flow) are collected at regular intervals and sent to the central forecasting office through radio communication, telephone and email for analysis and to prepare the flood bulletins. The national and local broadcast media is the most direct channel through which a warning reaches the public. People in the community often use only their indigenous knowledge to determine whether their places will be affected by hazards or not [11].

Bangladesh is a flood-prone country and extreme floods inundate more than half of the country almost every year. In the existing early flood warning system for Bangladesh, the hydrological data (rainfall and water level) for forecasting are received from the radar stations to the Flood Forecasting and
Warning Centre and combined with the data from the gauge reader staff (through mobile phone calls), but a decline in data quality has been found and impacted on the data accuracy for the flood forecasts. Disseminating flood information in Bangladesh to the public is through broadcast media, websites and the local dissemination points using mobile phones [14]. A recent study shows that Bangladeshis living in the flood-prone areas are receiving little information about floods through the existing warning dissemination media like TV, radio and newspapers, and the majority of them get flood information from local authorities and their neighbours[15].

South Africa suffers from annual floods. As part of the early warning system for flood forecasting and issuing warnings, real time data are transmitted from three sources (observation stations, radar and satellite) to the weather service centre. The received data is been processed at the centre using effective flood forecasting models which produce flood forecasts. In the case of a flood the information is distributed to communities at risk through mass media (radio, TVs and newspapers) and through the disaster management centre by emails, faxes, internet, emergency telephone calls and SMS messages. Moreover, communities can access the forecast information and flood status from the monitoring website [16].

\section{B. FWS in Developed Countries}

Many developed countries are affected by floods to the same degree as developing countries, but with less loss of life. This section discusses methods of a flood warning delivery in the selected developed countries.

For Australian flood warning systems, data is collected and communicated to the centres using a range of telemetry techniques. The most common techniques include radio, telephone, mobile phone, and satellite systems and increasingly internet-based technologies are coming into use.

Flood warnings have general and specific target audiences. The general warnings are disseminated to whole communities by broadcast media such as radio and television stations and the internet. The specific warnings to householders and individuals are by means of telephones, SMS, facsimiles, emails, two-way radio and doorknocking. In most floods in Australia, both categories of warnings have been used because it increases the likelihood of the message getting through[17].

In the United Kingdom, the flood warnings are provided by the Environment Agency using the latest technology to monitor rainfall, river level and sea conditions 24 hours a day. If flooding is forecast, the warning is issued directly to people living in areas at risk of flood through broadcasts media, radio and television. People who register for "the Flood line Warning Service" receive automatic warnings by telephone, SMS and email [18].

The Japan Meteorological Agency (JMA) provides residents with Earthquake and Tsunami Early Warnings. The system issues prompt alerts just as an earthquake starts through broadcast media (television, radio), mobile phone and sirens. Residents quickly prepare for an emergency after getting the warnings. The system has some limitations such as false warnings due to noise from an accident, lightning or device failure[19]. 
The United States operates the Integrated Public Alert and Warning System (IPAWS) sending an alert about natural hazards to the public. The system allows a single emergency alert message to be delivered to multiple communication systems as shown in Fig. 2. Messages are originated by the alerting authorities (federal, state or local level) using a range of national and local alert systems which receive weather data via Internet. The messages go to the IPAWS servers that gather the messages and authenticate them, the messages are then transmitted to the public through multiple paths: the Emergency Alert, Wireless Emergency Alert (WEA), Internet Service, National Oceanic and Atmosphere administration, and state and local alerting systems.

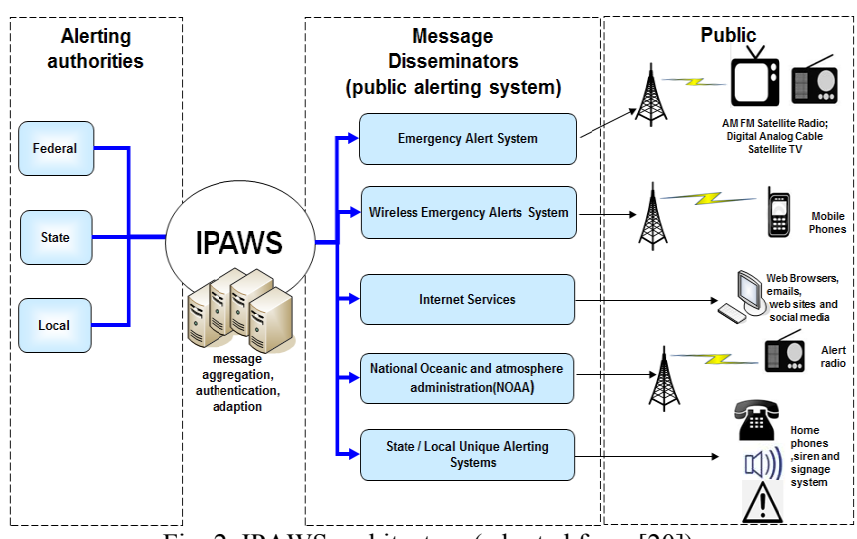

Fig. 2. IPAWS architecture (adopted from [20]).

Although the IPAWS allows an alert message to be communicated to the public through every available communication channels, it still has limitations such as the WEA has only 90 characters limit and some of the alerting systems have one-way communication like messages delivered through TV sets and radios [20].

\section{Discussions}

From the above background and the flood warning system review it can be seen that, there are many flood warning system methods in use around the world, and there is a number of factors that might relate to why developing countries are more vulnerable to floods than developed countries, some factors associated with these loses are the data collection process, the flood warning channels and an inappropriate use of technology.

\section{A. Data Collection Process}

Data collection is an important factor for flood forecasting and warning delays in collecting data may result in insufficient time to issue a warning.

From the above reviews it can be seen that collecting data for the flood warnings systems in developing countries are based on traditional tools which are through radio communication, facsimiles, telephones and emails. Even though, data collection in some countries like Laos has real-time data transmission systems, but some remote stations are still unreliable for the data transferring to the data centre[9], while in Bangladesh declining in quality of the collected data can results in an inaccuracy of a flood forecast and the warning[14].

For developed countries, data collection combines multiple networks to delivery real time data to the data centres; these networks include GSM network, satellite and internet. Obviously, transferring hydrological data for flood forecasting and warning in developed countries is more accurate because of using multiple networks to transmit data to the data centres.

\section{B. Flood Warning Channels}

Having sufficient time of warning can save more lives and minimizes property damage. Most flood warning channels in developing countries are broadcast media (radio and television stations), newspapers and websites. Even through broadcast media is the most direct channels for developing countries, but there will be an issue if the flood alert is sent via these channels at night time because a radio or TV set could be turned off[1].The newspaper is detailed and reached a wide audience, but it is too slow for a flash flood warning. The websites probably are not accessible by residents who live in flooded isolated areas and they may have not internet access.

Developed countries distribute flood information through multiple channels during floods. For example Australia use general and specific warnings in the most floods, general warnings (radio, TV and Internet) are disseminated to whole communities in flood risk areas, while specific warnings (telephone, two-way radio or door knocking) serve to reinforce and confirm the general warnings [17].

In United Stated, the Integrated Public Alert and Warning System allows a single alert message to be routed over many communication available devices, including mass media (radios and televisions), mobile phone (SMS), web browsers (websites, emails and social media), alert radio and home phones.

In this connection the flood warning systems in developed countries send a message through multiple channels to the public, while the systems in developing countries use few channel, so delivering flood information in developing countries has less chance to reach to the affected population in a timely manner.

\section{Inappropriate Technology Adaptation}

Using inappropriate technology to alert to the public during flood, people might not get the warnings due to them not having such technology with them.

It is also interesting to note that many developing countries have adopted a sophisticated flood warning system like those in developed countries such as or web-based flood systems. These systems in developing countries are unlikely to be accessible by the public due to people having lack of basic technological skill to use the technology. In other words people living in a flood risk area or working in farms (e.g.in a rice paddy) may not know how to access the web- based flood warnings or even they may not have access to the technology at all.

Moreover, the website may fail during the disaster because high demand of access. For example, during the 2009 severe bushfire in Victoria, the Country Fire Authority website was overwhelmed; it was unable to show warnings or a summary map of dangerous bushfire for a number of hours due to large number of people trying to access the sites; the servers could not cope with high load and network congestion[21].

So in order to get flood information on time during floods, 
the appropriate technology needs to be adopted. For instance, alerting the flood information through mobile phones may be more appropriate for developing countries.

\section{RECOMMENDATIONS}

From above discussion, the following recommendations are made:

\section{A. Combining Multiple Warning Methods}

Using multiple flood warning methods increases the probability that a warning will reach people in a flood risk area. In other words, the multiple methods help to ensure that people are more likely to be reached by at least one flood warning channel. For instance, people who live in remote areas might not receive the warning from TV sets, but they might be able to get the warning via SMS from mobile phones. Moreover, a two-way communication method is useful for warning because an end-user can contact the flood centre to ask for more specific information regarding warnings and allows the issuing authority to confirm receipt of the warning.

TABLE II: FLOOD WARNING COMMUNICATION METHODS(ADAPTED FROM[17])

\begin{tabular}{|c|c|c|c|}
\hline $\begin{array}{c}\text { Flood warning } \\
\text { methods }\end{array}$ & Advantages & Disadvantage & $\begin{array}{c}\text { Communication } \\
\text { Mode }\end{array}$ \\
\hline Sirens/alarms & $\begin{array}{l}\text { Quick } \\
\text { - Able to reach outdoor } \\
\text { populations }\end{array}$ & - May be misunderstood & One way \\
\hline SMS messages & $\begin{array}{l}\text { - Very quickly } \\
\text { - Can reach a wide } \\
\text { audience }\end{array}$ & $\begin{array}{l}\text { Mobile phone needs to be } \\
\text { switched on } \\
\text { - Depends on mobile phone } \\
\text { coverage }\end{array}$ & Two ways \\
\hline Radio & $\begin{array}{l}\text { - Fast speed } \\
\text { - Can reach a large } \\
\text { audience }\end{array}$ & $\begin{array}{l}\text { - Limited broadcast range } \\
\text { - Not available if the battery is } \\
\text { flat or power interruptions }\end{array}$ & One way \\
\hline Television & $\begin{array}{l}\text { - Ability to communicate } \\
\text { detailed information to } \\
\text { large audience, } \\
\text { - Ability to see graphics } \\
\text { and images }\end{array}$ & $\begin{array}{l}\text { - Broadcasts at the discretion of } \\
\text { station } \\
\text { - Not available when power } \\
\text { disrupted }\end{array}$ & One way \\
\hline $\begin{array}{l}\text { Websites/social } \\
\text { media/email }\end{array}$ & $\begin{array}{l}\text { - Quick dissemination } \\
\text { - Widely available }\end{array}$ & $\begin{array}{l}\text { - Internet required } \\
\text { - Not available in isolated areas } \\
\text { - Can be crash under high load }\end{array}$ & Two ways \\
\hline $\begin{array}{l}\text { Speaker phone/ } \\
\text { doorknocking }\end{array}$ & $\begin{array}{l}\text { - Direct and specific } \\
\text { communication }\end{array}$ & $\begin{array}{l}\text { - Requires access to flooded } \\
\text { areas }\end{array}$ & Two ways \\
\hline Print media & $\begin{array}{l}\text { - Informative/detailed, } \\
\text { - Ability to reach wide } \\
\text { audience }\end{array}$ & $\begin{array}{l}\text { - Slow } \\
\text { - Require access to flooded areas }\end{array}$ & One way \\
\hline Word of mouth & $\begin{array}{l}\text { Uses information from } \\
\text { multiple sources and } \\
\text { perspective }\end{array}$ & - Variable accuracy & Two ways \\
\hline
\end{tabular}

Table II shows different modes of the flood warnings with their advantage, drawback and communication modes [17].

\section{B. Warning Messages Need to be Clear and Understandable}

People in communities at risk of flood vary in age, flood experience, education and risk taking, and as a result understanding and translating the flood warning messages may vary. In many circumstances, the community seeks to confirm that the warning has been appropriately received and disseminated and they may not take action until they are satisfied with the warning messages.

In order to motivate the community of flood risk areas to quickly respond to a warning, the warning message must be friendly, comprehensible, persuasive and brief to avoid confusion. It should explain what is happening, where and how the flood will affect them [17].

\section{Using Available Technology}

Choosing the appropriate technology available in the country for a flood warning system is an advantage for both the residents in flood-prone areas and the flood forecasting authorities because the system must be readily available to the public. As noted developing countries are trying to adopt high technology in their countries without carefully considering appropriateness and service participation from the public.

The trend to using mobile phones in developing world is moderately high, in 2013 it has reached 89 mobile phone users per 100 and the number of mobile-broadband subscriptions has more than doubled from 2011 to 2013(from 472 million to 1.16 billion)[22].

As a result the above trend using SMS messages for alerting people in flood risk areas could be an effective tool as part of a flood warning mechanism for developing countries and using social media for a flood warning is also viable way for smart phone users.

\section{CONCLUSION AND FUTURE WORK}

This paper has reviewed the techniques of the flood warning system in parts of the word and discusses factors relating that developing countries are more venerable to flood then developed countries at the same level of severe flood as following:

Warning about floods in developing countries is through broadcast media (radio and television), print media and website which target just a general audience, whereas developed countries apply multiple communication channels for warning about floods to the public.

Factors that might result in more loss of life and property damage in developing countries as below:

1) Data collection process: In developing countries, collecting data mostly is based on traditional means (radio communication, facsimiles, telephones and emails) and transmitting data from the remote hydrological stations to the data centre is unreliable and 
the collected data has a lack of quality. These issues result in ineffective forecasting and warning.

2) Flood warning channels: Most flood warnings in developing countries are through broadcast media, newspapers and websites. For people in flood risk areas may not receive flood warnings in a timely manner if the warnings are available through these channels.

3) Inappropriate technology adoptation: Developing countries have jumped to adopt sophisticated flood warning systems such as web-based flood systems. These systems in developing countries are of limited accessibility by the public due to people having lack of basic technological skill to use the technology, and lack of means of access.

This paper recommends that in order to make an effective flood warning system, developing countries need to consider using multiple warning methods, understandable messages, and an appropriate technology available in each country.

Future work aims is to investigate a feasibility of using SMS message as a real-time flood warning system for developing countries: the case of Laos.

\section{ACKNOWLEDGMENTS}

This research is supported by an Australia Leadership Awards scholarship, for which we are very grateful.

\section{REFERENCES}

[1] S. Keoduangsine and R. Goodwin, "Appropriate flood warning system in the context of developing countries," International Journal of Innovation, Management, vol. 3, no. 3, pp. 213-216, 2012

[2] A. Ahmed. (2012). Death toll from typhoon Bopha tops 1000 in the Philippines. [Online]. Available: http://edition.cnn.com/2012/12/16/world/asia/philippines-typhoon/ind ex.html

[3] (2012). Mekong River Commision. 8th Annual Flood Forum. [Online]. Available:

http://www.mrcmekong.org/assets/Publications/conference/8th-annua 1-flood-forum.pdf

[4] H. Brecht. (2011). The World Bank. In Queensland no great barrier to flood recovery. [Online]. Available: http://blogs.worldbank.org/eastasiapacific/in-queensland-no-great-bar rier-to-flood-recovery

[5] S. Blake, T. Kimberlain, and R. Berg. (2013). Tropical Cyclone Report Hurricane Sandy. [Online]. Available: http://www.nhc.noaa.gov/data/tcr/AL182012_Sandy.pdf

[6] A. Roux. (2013). Storm Sandy: US death toll close to 100. [Online]. Available: http://www.bbc.co.uk/news/world-us-canada-20176908

[7] (2013). The Guardian: German flood damage insurance claims may reach $€ 3 \mathrm{bn}$ [Online]. Available: http://www.guardian.co.uk/world/2013/jun/11/german-flood-damageinsurance-claims

[8] (2013). Mekong River Commission: Mekong River Real-Time Monitoring. [Online]. Available: http://monitoring.mrcmekong.org/

[9] (2010). Mekong River Commission. "Flood Situation Report,"The MRC Technique Papers, [Online]. Available: http://www.mrcmekong.org/assets/Publications/technical/Tech-No36Flood-Situation-Report2011.pdf

[10] S. Keoduangsine and R. Goodwin, "A GPRS-Based data collection and transmission for flood warning system: The case of the Mekong river basin," International Journal of Innovation, Management, vol. 3, no. 3, pp. 217-220, 2012.

[11] L. Garcia. (2007). Overview of early flood warnig system for hydro-meteorological hazard in the selected countries in Southest Asia, [Online].

Available: http://www.icimod.org/?opg=949\&q=drr_document\&document $=1373$

[12] K. Yoshiaki and P. Jonh, "Flood risk management in the People's Republic of China," Asia Development Bank, pp. 1-12, 2012.

[13] J. Ma, "Flood management and flood warning system in China," Irrigation and Drainage, vol. 59, no. 1, pp. 17-22, 2010.
[14] DANIDA. (2006). Consolidation and Strengthening of Flood Forecasting and Warning Service. [Online]. Available: $\mathrm{http} / / /$ bangladesh.um.dk/en/danida-en/climate-change-adoption-and-d isaster-risk-reduction/support-to-national-flood-forecasting-and-warni ng-services-bangladesh/

[15] M. Rahman, N. Goel, and S. Arya, "Study of early flood warning dissemination system in Bangladesh," Journal of Flood Risk Management, vol. 2, 2012.

[16] E. Poolman. (2012). Early warning system. [Online]. Available: http://www.kzncogta.gov.za/Portals/0/Documents/DisasterManageme nt/No.\%203\%20Early\%20Warning\%20Systems\%20EP.pdf

[17] M. Studdert. (2009). Australia emergency manual series: Australian emergency management. [Online]. Available: http://www.em.gov.au/Documents/Manual\%2021-Flood\%20Warning $\% 282 \% 29$.PDF

[18] (2013). UK Environment Agency: The Flood Warning Service. [Online]. Available: http://www.environment-agency.gov.uk/homeandleisure/floods/58417 .aspx

[19] (2013). Japan Meteorological Agency: Earthquake Early Warning. [Online]. Available: http://www.jma.go.jp/jma/en/Activities/eew.html

[20] M. Lucero. (2013). US Federal Emergengy Management Service: Integrated Public Alert and Warning System. [Online]. Available: http://www.fema.gov/media-library/assets/documents/34096

[21] (2010). ABC news: CFA website crashes as bushfire treat escalates. [Online]. Available: http://www.abc.net.au/news/2010-01-11/cfa-website-crashes-as-bushf ire-threat-escalates $/ 1204500$

[22] (2010). ITU: ICT Facts and Figures. [Online]. Available: http://www.itu.int/en/ITU-D/Statistics/Documents/facts/ICTFactsFigu res2013.pdf

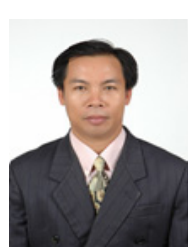

Saysoth Keoduangsine received his master agree in information technology (computing) from Flinders University of South Australia in 2005. He was having five years of international organization experience in the Mekong river commission secretariat in Laos, along with tree years of part-time teaching experience from 2006 to 2009. At the present, he is pursuing his $\mathrm{PhD}$ of computer science at the Flinders University, his research focuses on an SMS-based flood warning system in developing countries.

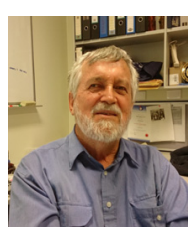

Robert Goodwin resides in Adelaide, South Australia, and received his BSc with honors (communication studies) from university of South Australia and $\mathrm{PhD}$ in Physics from university of Adelaide, Australia. He has always enjoyed teaching both at high school and University levels in Physics, Mathematics and Science Education, and is currently Senior Lecture in Information Technology at Flinders University of South Australia. His research interests relate to the application of information technology in business and education. In particular, he is interested in developing models for strategic planning in the application of ICT in developing countries. Dr. Goodwin is a research program leader, member of Australian Computer Society, member of the programming committee and peer reviewer for 5 International conferences.

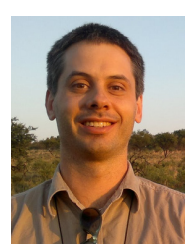

Paul Gardner-Stephen resides in Adelaide, South Australia, and received his BSc (computer science) in 2001 and $\mathrm{PhD}$ (computer systems engineering) in 2008 from Flinders University, Adelaide, Australia. $\mathrm{He}$ is currently Rural, Remote \& Humanitarian Telecommunications Research Fellow at Flinders University, Adelaide, Australia, and President of Serval Project Inc., having previously served as a Shuttleworth Telecommunications Fellow, Lecturer in Computer Science, Resident Scientist for ABC 891 Adelaide, and Computer \& Network Systems Administrator. His research interests focus on resilient communications, in particular infrastructure-independent mobile telecommunications for humanitarian applications, SPAM, computer security and distributed systems. Dr. Gardner-Stephen is a Shuttleworth Fellow, board member of the Flinders University Disaster Research Centre, South Australian Tall Poppy, Technology Challenge for Atrocity Prevention laureate, as well as past finalist in competitions and challenges including the Global Security Challenge and Ashoka Change-Makers. 